\title{
Research on the Relationship Between Marathon Participants' Satisfaction and Willingness to Participate under Experience Value Perspective
}

\author{
Wenmin Jin* \\ Shenzhen Campus of Jinan University, China.
}

*Corresponding Authors: Wenmin Jin, Shenzhen Campus of Jinan University, China.

\begin{abstract}
Marathon activities are booming in China, but the research of participants' experience is lacking. In this paper, the experience value dimension is verified among marathon participants, and the relationship between satisfaction and willingness to participate is discussed by using structural equation model. The results show that :(1) the perceived experience of marathon participants can be divided into four dimensions from high to low: economic experience value, hedonic experience value, altruistic experience value and social experience value. (2) economic experience value and altruistic experience value have a significant positive impact on the satisfaction, and the impact of economic experience value is greater. While hedonic experience value and social experience value have no significant impact on the satisfaction. (3) participants' satisfaction will have a positive impact on the participation willingness.
\end{abstract}

Key words: Marathon; Experience value; Participation willingness; structural equation model

\section{INTRODUCTION}

Entering the decisive stage of building a moderately prosperous society in an all-round way in China, people's income has been increased, together with leisure time which leads to the coming of leisure era. National fitness has become a national strategy. The enhancement of people's health awareness makes more and more people realize the importance of sports. Among the various sports methods, running is simple and easy way and is highly praised. Marathon in various forms and themes has shown a blowout development in China. According to the annual report of <China Marathon 2018>, at the end of 2018, there were 1581 marathons and related sports events (road races with more than 800 people and cross-country races with more than 300 people) in China, with a total of 5.83 million participants.

Recently, experience has gone beyond products and services. It is a beautiful, unforgettable and unique process that people experience which refers to a kind of beautiful feeling produced in people's consciousness when people's emotion, body, intelligence and even spirit reach a certain level(Yu and Zhang, 2015; $\mathrm{Wu}$, Cheng, Ai,2018).The research on experience value has shifted from product field to leisure field, and it has theoretical and practical significance for the research of consumer experience. Experience value has been achieved in different fields (Song and Yao, 2013; Prebensen, Woo, Uysal,2014; Michie and Gooty, 2005).

As an increasing number of Marathon participants, what experience they can get from the activities still needs exploration. Some scholars have begun to explore the psychological experience of participants by qualitative research methods ( $\mathrm{Li}$ and $\mathrm{Li}, 2019$; Huang and Zhang,2019). This study will try to focus on the problems: what kind of experience can participants get in marathon activities under the existing framework dimension of experience? How does the experience affect their satisfaction and willingness to participate? We hope to provide some theoretical basis for the organizers and participants of the city marathon.

\section{LITERATURE REVIEW}

The concept of experience exists in many disciplines. Different scholars in economics, management, psychology and many other disciplines have defined this concept from different perspectives. From the perspective of economics, experience is not only sold to customers as accessories when the 
audience enjoys the service, but also sold to the audience at a certain price as if the commodity has its own value (Pine and Gilmore,1998). Pine et al. (1998) pointed out that experience is an event in which each customer participates in a personalized way. Schmitt (1999) pointed out that experience is an individual's response to some stimuli (such as marketing efforts). Wen (2007) indicated that businesses will create an appropriate atmosphere to infect the audience in order to promote or publicize products. In this case, the emotional reaction of the audience to the products, personnel and services of the businesses in the process of contacting with the businesses is experience (Sweeney and Soutar, 2001). In reality, experience is more and more used in the service industry.

There is no consistent view on the dimension of experience. Pine et al. (1998) thinks that it should include entertainment experience, education experience, recluse experience and aesthetic experience. According to Schmitt (1999), it includes sensory experience, emotional experience, thinking experience, action experience and relevance experience. Sweeney et al. (2001) divided the retail consumer experience into emotional experience, quality / performance experience, social experience and price experience. Mathwick, Malhotra and Rigdon (2001) pointed out that customer perceived experience value interacts with long-distance appreciation or direct use of products and services. The brand value of the resort is related to customers' experience before, during and after consumption. Therefore, they believe that under the context of the resort, customers' experience should be understood from the following four dimensions: internal environment, interest, return on investment and excellent service facilities.

Li (2017) explored the four dimensions of tourists' leisure experience: entertainment experience, education experience, escape experience, aesthetic experience and their environmental responsible behavior. Li and Fan(2006) divided service experience into three dimensions: (1) Functional experience, including product experience, environment experience and employee service experience. (2) Emotional experience is the affection, mood or feelings that customers are aroused in the process of consumption. (3) Social experience is a kind of functional or symbolic value. Consumption is to establish a kind of social relationship and seek a sense of social belonging and identity. They believe that in the process of consumption, the first thing customers need is functional value, the second is emotional value, and the last is social value that highlights their own status and taste. Yang and Chen (2010) followed Holbrooke's classification and divided customer experience into four kinds of experience value ideology: (1) Economic experience value refers to consumers' requirements for high quality and efficiency of goods and services. (2) Hedonic experiential value refers to the sense of pleasure, aesthetics and comfort that consumers can experience when they get goods and corresponding services. (3) Social experiential value is mainly reflected in that consumers regard purchasing behavior as a means of reflecting social status and social value. (4) Altruistic empirical value refers to the impact of consumers' purchasing activities on others and society.

From the above classification, we can find that the division of experience will be different due to the different nature of products or services. Since marathon is not a physical product, participants will be weak in the functional experience, and more concentrated in the emotional and social experience. Wang (2018) pointed out that with the help of running, an individual's body has such social functions as symbol, consumption, narration, communication, and identification. Wang et al. (2017) believe that marathon is a performing platform for the realization of group-value and self-value, and marathon running can be transformed into the recognition and pursuit of community value. Li et al. (2019) found that the psychological experience of City Marathon competitors includes four categories: cognition, emotion, will and special experience. Therefore, based on the division of various dimensions of experience, this study divides it into economic experience value, hedonic experience value, social experience value and altruistic experience value referring to the characteristics of Marathon participants.

The research on experience value and satisfaction shows that value has a positive impact on satisfaction. Wu and Liang (2009) show that service-related factors will have a positive impact on customer satisfaction through experience value. Prebensen et al. (2014) also pointed out that experience value has an impact on satisfaction. Therefore, this paper puts forward the following hypotheses:

\section{H1: experience value will have a positive impact on marathon participants' satisfaction}


Research on the Relationship Between Marathon Participants' Satisfaction and Willingness to Participate under Experience Value Perspective

H1a: economic experience value will have a positive impact on marathon participants' satisfaction

H1b: hedonic experience value will have a positive impact on marathon participants' satisfaction

H1c: social experience value will have a positive impact on marathon participants' satisfaction

H1d: altruistic experience value will have a positive impact on marathon participants' satisfaction

The impact of satisfaction on loyalty and willingness to participate has also been confirmed in many fields. For example, in the field of tourism and reception industry, the impact of experience value on post purchase behavior is recognized (Chang,2018; Ahn, Lee, Back,2019). Research by Wu et al. (2018) shows that experience satisfaction of cruise tourists will have a positive impact on behavior intention. Therefore, the study proposes $\mathrm{H} 2$ :

\section{H2: satisfaction will have a positive impact on the willingness to continue to participate.}

\section{METHODOLOGY}

Based on the existing researches, this study divides marathon participants' experience into four dimensions: economic experience value, hedonic experience value, social experience value and altruistic experience value. In order to design items more objectively, this study first conducted a content analysis of Marathon participants' feelings after competitions (16803 words in total) in the above four dimensions, and the summary is shown in Table 1 . The content was obtained through internet from the travel notes and diaries of the Marathon participants.

Table1. Experience dimensions of Marathon participants based on feelings after competitions

\begin{tabular}{|c|c|c|}
\hline Dimensions & $\begin{array}{l}\text { Typical descriptions of feelings after } \\
\text { competitions }\end{array}$ & Summary \\
\hline $\begin{array}{l}\text { Economic } \\
\text { experience } \\
\text { value }\end{array}$ & $\begin{array}{l}\text { Running is the most economical way of fitness, no } \\
\text { equipment, no professional venues, no company, } \\
\text { no time limit. Especially that the picturesque hills } \\
\text { and streams in the back garden of our village are } \\
\text { stunning, the air is fresh. It is like a crime if you do } \\
\text { not run. } \\
\text { Although marathon is a competitive sport, in my } \\
\text { humble opinion, it is a good activity for national } \\
\text { fitness and entertainment. So that a lot of friends at } \\
\text { the scene come to the game and play together. }\end{array}$ & $\begin{array}{l}\text { Marathon participants generally } \\
\text { believe that running is a healthy and } \\
\text { inexpensive activity. At the same time, } \\
\text { the route selection of Marathon usually } \\
\text { has a better environment, which can let } \\
\text { them also experience local customs } \\
\text { and get a better experience than } \\
\text { expected, acting like a good } \\
\text { adjustment to the daily life. }\end{array}$ \\
\hline $\begin{array}{l}\text { Hedonic } \\
\text { experience } \\
\text { value }\end{array}$ & $\begin{array}{l}\text { Some people say that "life is a run with an end". } \\
\text { Like Forrest Gump, he keeps on running, keeps on } \\
\text { walking, and changes other people's lives without } \\
\text { pause. During running, we throw away the past, } \\
\text { learn to be tolerant, and find the true meaning of } \\
\text { life, which is one of the reasons why people love } \\
\text { marathon. } \\
\text { It is the eighth time that I came to this track, } \\
\text { everything was so familiar, as if I went home. How } \\
\text { much can I run is not so important to me. It is the } \\
\text { most perfect result to run well and run PB; If not, } \\
\text { just enjoy the track and feel the annual feeling. }\end{array}$ & $\begin{array}{l}\text { Most of the members will have a sense } \\
\text { of pleasure in the process of } \\
\text { participation, either from the beauty } \\
\text { and elegance of the surrounding } \\
\text { landscape, or from the baptism of life } \\
\text { and their own ideas, or from the } \\
\text { reunion with new and old friends, or } \\
\text { from the passion supplement to the } \\
\text { plain life. In a word, it can be found in } \\
\text { the description that the participants } \\
\text { have hedonic } \\
\text { characteristics. }\end{array}$ \\
\hline $\begin{array}{l}\text { Social } \\
\text { experience } \\
\text { value }\end{array}$ & $\begin{array}{l}\text { This process, for athletes, is not a competition, and } \\
\text { a self- transcendence. We tried to run on the field } \\
\text { together, and learned to insist in the process of } \\
\text { running. } \\
\text { Every time they finish a competition, they have } \\
\text { completed a challenge for themselves. When they } \\
\text { rush through the finish line, they will gain enough } \\
\text { to benefit from their life. }\end{array}$ & $\begin{array}{l}\text { Participants believe that marathon is a } \\
\text { race against themselves. Maybe it's } \\
\text { reflected in the better results you can } \\
\text { get in each run, maybe it's reflected in } \\
\text { the perseverance you get. Participants } \\
\text { believe that marathon can produce } \\
\text { social experience beyond self. }\end{array}$ \\
\hline $\begin{array}{l}\text { Altruistic } \\
\text { experience } \\
\text { value }\end{array}$ & $\begin{array}{l}\text { The participants who prepared before the } \\
\text { competition and the audience were instantly } \\
\text { touched and joined in the hot dance. Several young } \\
\text { French dancers also joined in, taking pictures one } \\
\text { after another. It more like a carnival instead of a }\end{array}$ & $\begin{array}{l}\text { Results are important, but so is the } \\
\text { atmosphere of the game. Many } \\
\text { participants mentioned in their } \\
\text { descriptions that the racers had a good } \\
\text { relationship during the race, cheered }\end{array}$ \\
\hline
\end{tabular}


Research on the Relationship Between Marathon Participants' Satisfaction and Willingness to Participate under Experience Value Perspective

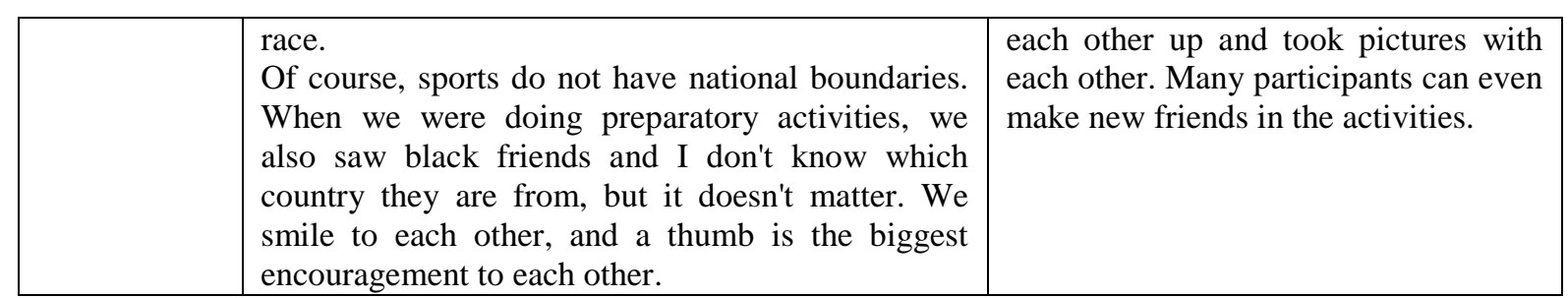

According to the above description, and referring to the relevant literature and the actual situation of Marathon activities, the item design is carried out (as shown in Table 2), and the questionnaire is designed according to the Likert five subscale.

Table2. Source of questionnaire items

\begin{tabular}{|c|c|c|}
\hline Dimensions & Items & Source \\
\hline \multirow{4}{*}{$\begin{array}{l}\text { Economic } \\
\text { experience } \\
\text { value }\end{array}$} & $\begin{array}{l}\text { Taking part in the Marathon is a convenient and efficient way } \\
\text { to improve the quality of life }\end{array}$ & Yang et al. (2010) \\
\hline & Taking part in the marathon effectively improved my health & \\
\hline & $\begin{array}{l}\text { Taking part in the marathon has effectively improved my } \\
\text { attitude towards life }\end{array}$ & \\
\hline & Taking part in the marathon effectively enriched my free time & \\
\hline \multirow{4}{*}{$\begin{array}{l}\text { Hedonic } \\
\text { experience } \\
\text { value }\end{array}$} & Taking part in the marathon made me relax completely & Wang et al. (2018) \\
\hline & $\begin{array}{l}\text { Taking part in the marathon helped me relieve the pressure and } \\
\text { calm down }\end{array}$ & \\
\hline & $\begin{array}{l}\text { Taking part in the Marathon gives me a sense of stress and } \\
\text { security }\end{array}$ & \\
\hline & Taking part in the Marathon gives me a sense of freedom & \\
\hline \multirow{3}{*}{$\begin{array}{l}\text { Social } \\
\text { experience } \\
\text { value }\end{array}$} & $\begin{array}{l}\text { Taking part in the Marathon makes me gain encouragement } \\
\text { and praise from others, and I feel more confident }\end{array}$ & $\begin{array}{l}\text { Li J et al. (2006); ;Huang } \\
\text { et al. (2019) }\end{array}$ \\
\hline & $\begin{array}{l}\text { Taking part in the Marathon can let me feel my own sense of } \\
\text { existence. }\end{array}$ & \\
\hline & $\begin{array}{l}\text { I explore myself, explore my potential and feel satisfied in } \\
\text { every marathon. }\end{array}$ & \\
\hline \multirow{3}{*}{$\begin{array}{l}\text { Altruistic } \\
\text { experience } \\
\text { value }\end{array}$} & I'm free to express trust with other marathon enthusiasts & Wang et al. (2006) \\
\hline & $\begin{array}{l}\text { I have a stress free, easy interaction experience with other } \\
\text { marathon enthusiasts }\end{array}$ & \\
\hline & Marathon brings upward atmosphere into the whole society & \\
\hline \multirow{3}{*}{$\begin{array}{l}\text { Willingness } \\
\text { to } \\
\text { participate }\end{array}$} & I'm very willing to continue running marathons & $\mathrm{Wu}(2018)$ \\
\hline & It's very difficult for me to give up the marathon & \\
\hline & I'm very determined to keep running & \\
\hline \multirow[t]{3}{*}{ Satisfaction } & $\begin{array}{l}\text { I'm satisfied with the sense of accomplishment that marathon } \\
\text { brings }\end{array}$ & $\begin{array}{l}\text { Wu et al. (2018);Yang } \\
\text { Yun et al. (2010) }\end{array}$ \\
\hline & I'm satisfied that running a marathon helps me relax & \\
\hline & $\begin{array}{l}\text { I'm satisfied that running a marathon has challenged my } \\
\text { physical fitness }\end{array}$ & \\
\hline
\end{tabular}

This study collected data through questionnaire survey and conducted from December 2018 to February 2019. The questionnaire was mainly distributed during the Nanshan Marathon in Shenzhen. In addition, 218 valid questionnaires were collected through online distribution among marathon lovers in Hunan. The sample profile is shown in Table 3, from which we can find that the proportion of men and women is relatively balanced. The Post-70s, 80s and 90s are the main groups of the survey, and $59.2 \%$ of the sample group have participated in more than three marathons.

Table3. Sample profile

\begin{tabular}{|c|c|c|c|c|c|}
\hline \multirow[b]{2}{*}{ Gender } & \multirow{2}{*}{\begin{tabular}{|l|} 
Male \\
Female
\end{tabular}} & \multirow{2}{*}{$\begin{array}{l}54.1 \\
45.9\end{array}$} & \multirow{3}{*}{ Occupation } & Shenzhen & \multirow{2}{*}{$\begin{array}{l}27.5 \\
36.1\end{array}$} \\
\hline & & & & $\begin{array}{l}\text { Other places in } \\
\text { Guangdong Province }\end{array}$ & \\
\hline \multirow{2}{*}{ Age } & post-2000s & 8.3 & & $\begin{array}{ll}\text { Outside } & \text { Guangdong } \\
\text { Province } & \end{array}$ & 35.8 \\
\hline & post-1990s & 33.5 & Frequency & 1st time & 30.7 \\
\hline
\end{tabular}


Research on the Relationship Between Marathon Participants' Satisfaction and Willingness to Participate under Experience Value Perspective

\begin{tabular}{|c|c|c|c|c|c|}
\hline & post-1980s & 22.9 & & Twice & 10.1 \\
\hline & post-1970s & 28.4 & & Three times and above & 59.2 \\
\hline & post-1960s & 6.9 & \multirow{5}{*}{$\begin{array}{l}\text { Working } \\
\text { situation }\end{array}$} & Full-time job & 54.1 \\
\hline \multirow{4}{*}{ Education } & No formal education & 0.5 & & Part-time job & 6 \\
\hline & $\begin{array}{l}\text { High school and } \\
\text { below }\end{array}$ & 25.2 & & Student & 26.6 \\
\hline & Bachelor degree & 69.3 & & Retired & 3.2 \\
\hline & $\begin{array}{l}\text { Master degree and } \\
\text { above }\end{array}$ & 5 & & others & 10.1 \\
\hline
\end{tabular}

\section{FINDINGS}

\subsection{Reliability and Validity Examination}

The Cronbach's alpha value of 20 items in the questionnaire is 0.965 , and the Cronbach's alpha values of experience, satisfaction and willingness to participate are $0.958,0.785$ and 0.895 respectively, which are all greater than 0.8. In addition, the measurement indexes of each item do not meet the deletion conditions which means they have good reliability.

Exploratory factor analysis shows that the KMO value of the experience scale is 0.921 , greater than 0.7. As shown in Table 4, the factor load of each item is above 0.5 , and the cumulative variance explanation rates of experience, satisfaction and willingness to participate namely are $81.684 \%$, $70.903 \%$ and $77.481 \%$, respectively, which are all more than $60 \%$, indicating that the factors retained after extraction are quite well (Wu, 2010: 232), and there is good stability and internal consistency among the measurement items of the scale.

Table4. Results of CFA

\begin{tabular}{|c|c|c|c|}
\hline Dimensions & Items & $\begin{array}{l}\text { Factor } \\
\text { load }\end{array}$ & $\begin{array}{l}\text { Variation of } \\
\text { interpretation }(\%)\end{array}$ \\
\hline \multirow{4}{*}{$\begin{array}{l}\text { Economic } \\
\text { experience value }\end{array}$} & $\begin{array}{l}\text { Taking part in the Marathon is a convenient and } \\
\text { efficient way to improve the quality of life }\end{array}$ & 0.651 & \multirow{4}{*}{21.685} \\
\hline & $\begin{array}{l}\text { Taking part in the marathon effectively improved } \\
\text { my health }\end{array}$ & 0.804 & \\
\hline & $\begin{array}{l}\text { Taking part in the marathon has effectively } \\
\text { improved my attitude towards life }\end{array}$ & 0.698 & \\
\hline & $\begin{array}{l}\text { Taking part in the marathon effectively enriched } \\
\text { my free time }\end{array}$ & 0.721 & \\
\hline \multirow{4}{*}{$\begin{array}{l}\text { Hedonic } \\
\text { experience value }\end{array}$} & $\begin{array}{l}\text { Taking part in the marathon made me relax } \\
\text { completely }\end{array}$ & 0.689 & \multirow{4}{*}{21.621} \\
\hline & $\begin{array}{l}\text { Taking part in the marathon helped me relieve } \\
\text { the pressure and calm down }\end{array}$ & 0.651 & \\
\hline & $\begin{array}{l}\text { Taking part in the Marathon gives me a sense of } \\
\text { stress and security }\end{array}$ & 0.766 & \\
\hline & $\begin{array}{l}\text { Taking part in the Marathon gives me a sense of } \\
\text { freedom }\end{array}$ & 0.773 & \\
\hline \multirow[t]{3}{*}{$\begin{array}{l}\text { Social } \\
\text { experience value }\end{array}$} & $\begin{array}{l}\text { Taking part in the Marathon makes me gain } \\
\text { encouragement and praise from others, and I feel } \\
\text { more confident }\end{array}$ & 0.691 & 20.286 \\
\hline & $\begin{array}{l}\text { Taking part in the Marathon can let me feel my } \\
\text { own sense of existence. }\end{array}$ & 0.822 & \\
\hline & $\begin{array}{l}\text { I explore myself, explore my potential and feel } \\
\text { satisfied in every marathon. }\end{array}$ & 0.700 & \\
\hline \multirow{3}{*}{$\begin{array}{l}\text { Altruistic } \\
\text { experience value }\end{array}$} & $\begin{array}{l}\text { I'm free to express trust with other marathon } \\
\text { enthusiasts }\end{array}$ & 0.764 & \multirow{3}{*}{18.092} \\
\hline & $\begin{array}{l}\text { I have a stress free, easy interaction experience } \\
\text { with other marathon enthusiasts }\end{array}$ & 0.815 & \\
\hline & $\begin{array}{l}\text { Marathon brings upward atmosphere into the } \\
\text { whole society }\end{array}$ & 0.740 & \\
\hline \multirow{2}{*}{$\begin{array}{l}\text { Willingness to } \\
\text { participate }\end{array}$} & I'm very willing to continue running marathons & 0.888 & \multirow{2}{*}{77.481} \\
\hline & It's very difficult for me to give up the marathon & 0.833 & \\
\hline
\end{tabular}


Research on the Relationship Between Marathon Participants' Satisfaction and Willingness to Participate under Experience Value Perspective

\begin{tabular}{|c|c|c|c|}
\hline & I'm very determined to keep running & 0.918 & \\
\hline \multirow{3}{*}{ Satisfaction } & $\begin{array}{l}\text { I'm satisfied with the sense of accomplishment } \\
\text { that marathon brings }\end{array}$ & 0.760 & \multirow{3}{*}{70.903} \\
\hline & $\begin{array}{l}\text { I'm satisfied that running a marathon helps me } \\
\text { relax }\end{array}$ & 0.873 & \\
\hline & $\begin{array}{l}\text { I'm satisfied that running a marathon has } \\
\text { challenged my physical fitness }\end{array}$ & 0.887 & \\
\hline
\end{tabular}

On the basis of the above, we use the maximum likelihood estimation method in AMOS to carry out confirmatory factor analysis on the four dimensions of experience. The results show that RMSEA = 0.093, greater than 0.08, which needs to be modificated. Judging from M.I., we need to delete two items: "Taking part in the Marathon effectively improves my attitude towards life" and "Taking part in the Marathon makes me feel free".

Further examination of the indicators after deleting the items finds that, $\chi^{2} / \mathrm{df}=2.299$, less than 3 ; RMSEA $=0.077$, less than 0.08; GFI=0.929, NFI=0.950, RFI $=0.931$, IFI $=0.971, \mathrm{CFI}=0.971$, all of which are greater than 0.9 , only $\mathrm{AGFI}=0.885$, very close to 0.9 , which indicates that the four dimensions of the measurement model have better fitting advantages.

It can be seen from table 5 that the critical ratios of four dimensions of experience are all greater than 1.96, which is significant at the level of $\mathrm{P}<0.05$. The standardized factor loads of 12 items are all greater than 0.7 , indicating that the scale has good aggregate validity. The combined reliability CR of economic experience value, hedonic experience value, social experience value and altruistic experience value are $0.846,0.904,0.882$ and 0.905 , which are all greater than 0.7 , The average extraction variance (AVE) were 0.647, 0.758, 0.731, 0.762, all greater than 0.5, which met the test standard of the model. At the same time, the average extraction variance of satisfaction and willingness to participate were 0.584 and 0.674 , respectively, which were greater than 0.5 , and the combined reliability were 0.804 and 0.860 , respectively, which were greater than 0.7 . Therefore, it can be judged that the item has content validity to the interpretation of the concept.

Table5. Results of confirmatory factor analysis

\begin{tabular}{|c|c|c|c|c|c|c|c|}
\hline Dimensions & Items & $\begin{array}{l}\text { Average } \\
\text { value }\end{array}$ & $\begin{array}{l}\text { Normalized } \\
\text { factor load }\end{array}$ & $\begin{array}{l}\text { Critical } \\
\text { ratio }\end{array}$ & $P$ value & $\begin{array}{l}\text { Combined } \\
\text { reliability }\end{array}$ & $\begin{array}{l}\text { Average } \\
\text { extraction } \\
\text { variance }\end{array}$ \\
\hline \multirow{4}{*}{$\begin{array}{l}\text { Economic } \\
\text { experience } \\
\text { value }\end{array}$} & $\begin{array}{l}\text { Taking part in the Marathon is a } \\
\text { convenient and efficient way to }\end{array}$ & 3.87 & 0.749 & & & \multirow{4}{*}{0.846} & \multirow{3}{*}{0.647} \\
\hline & $\begin{array}{l}\text { Taking part in the marathon } \\
\text { effectively improved my health }\end{array}$ & 4.06 & 0.801 & 11.74 & $* * *$ & & \\
\hline & $\begin{array}{l}\text { Taking part in the marathon has } \\
\text { effectively improved my attitude }\end{array}$ & 4.00 & 0.859 & 12.59 & $* * *$ & & \\
\hline & $\begin{array}{l}\text { Taking part in the marathon } \\
\text { effectively enriched my free time }\end{array}$ & 4.00 & 0.829 & & & & \multirow{3}{*}{0.758} \\
\hline \multirow{2}{*}{$\begin{array}{l}\text { Hedonic } \\
\text { experience } \\
\text { value }\end{array}$} & $\begin{array}{l}\text { Taking part in the marathon made me } \\
\text { relax completely }\end{array}$ & 3.98 & 0.919 & 17.26 & $* * *$ & \multirow[t]{2}{*}{0.904} & \\
\hline & $\begin{array}{l}\text { Taking part in the marathon helped } \\
\text { me relieve the pressure and calm } \\
\text { down }\end{array}$ & 3.91 & 0.861 & 15.62 & $* * *$ & & \\
\hline \multirow[b]{3}{*}{$\begin{array}{l}\text { Social } \\
\text { experience } \\
\text { value }\end{array}$} & $\begin{array}{l}\text { Taking part in the Marathon gives me } \\
\text { a sense of stress and security }\end{array}$ & 3.83 & 0.877 & & & \multirow[b]{3}{*}{0.882} & \multirow[b]{3}{*}{0.713} \\
\hline & $\begin{array}{l}\text { Taking part in the Marathon gives me } \\
\text { a sense of freedom }\end{array}$ & 3.74 & 0.799 & 14.55 & $* * *$ & & \\
\hline & $\begin{array}{l}\text { Taking part in the Marathon makes } \\
\text { me gain encouragement and praise } \\
\text { from others, and I feel more confident }\end{array}$ & 3.89 & 0.856 & 16.25 & $* * *$ & & \\
\hline \multirow{3}{*}{$\begin{array}{l}\text { Altruistic } \\
\text { experience } \\
\text { value }\end{array}$} & $\begin{array}{l}\text { Taking part in the Marathon can let } \\
\text { me feel my own sense of existence. }\end{array}$ & 3.80 & 0.936 & & & \multirow{3}{*}{0.905} & \multirow{3}{*}{0.762} \\
\hline & $\begin{array}{l}\text { I explore myself, explore my potential } \\
\text { and feel satisfied in every marathon. }\end{array}$ & 3.89 & 0.923 & 22.77 & $* * *$ & & \\
\hline & $\begin{array}{l}\text { I'm free to express trust with other } \\
\text { marathon enthusiasts }\end{array}$ & 3.98 & 0.746 & 14.43 & $* * *$ & & \\
\hline \multirow{3}{*}{$\begin{array}{l}\text { Willingness } \\
\text { to } \\
\text { participate }\end{array}$} & $\begin{array}{l}\text { I have a stress free, easy interaction } \\
\text { experience with other marathon }\end{array}$ & 4.01 & 0.821 & & & \multirow{3}{*}{0.860} & \multirow{3}{*}{0.674} \\
\hline & $\begin{array}{l}\text { Marathon brings upward atmosphere } \\
\text { into the whole society }\end{array}$ & 3.68 & 0.698 & 11.02 & $* * *$ & & \\
\hline & $\begin{array}{l}\text { I'm very willing to continue running } \\
\text { marathons }\end{array}$ & 3.89 & 0.928 & 12.8 & $* * *$ & & \\
\hline \multirow{3}{*}{ Satisfaction } & $\begin{array}{l}\text { It's very difficult for me to give up the } \\
\text { marathon }\end{array}$ & 4.06 & 0.578 & & & \multirow{3}{*}{0.804} & \multirow{3}{*}{0.584} \\
\hline & I'm very determined to keep running & 4.03 & 0.813 & 10.01 & $* * *$ & & \\
\hline & $\begin{array}{l}\text { I'm satisfied with the sense of } \\
\text { accomplishment that marathon brings }\end{array}$ & 4.01 & 0.870 & 9.989 & $* * *$ & & \\
\hline
\end{tabular}


In addition, from the average value of each dimension of experience in the above table, we can find that from high to low, it is economic experience value (3.98), hedonic experience value (3.96), altruistic experience value (3.89) and social experience value (3.82). From the average of each item, although the difference is not big, the top five items are: Taking part in the Marathon effectively improves my health (4.06), taking part in the Marathon effectively enriches my free time (4.00), taking part in the Marathon makes me relax (4.00), taking part in the Marathon makes me relieve pressure and calm down(3.98), taking part in the Marathon makes me relax (4.00) Marathon brings upward atmosphere into the whole society (3.98). Generally, the average satisfaction of participants to marathon is 4.03 , and the average willingness to continue to participate is 3.86 .

\subsection{Path Testing}

The sample data is imported into AMOS 21.0 for calculation and analysis, and the analysis results show the validity of the model $\chi^{2} / \mathrm{df}=2.241$, less than 3 ; RMSEA $=0.076$, less than 0.08 . Most of the other indicators are above 0.9 , only GFI $=0.897$, AGFI $=0.831$ is slightly lower than 0.9 (as shown in Table 6), indicating that the goodness of fit of the initial measurement model is acceptable, but some indicators do not meet the standard, so the model needs to be modified by individual path.

The criteria of path coefficient significance examination are: when the critical ratio is greater than 1.96 , it is significant at the level of $\mathrm{P}<0.05$; when the critical ratio is greater than 2.58 , it is significant when $\mathrm{P}<0.01$. The results show that the $\mathrm{P}$ values of hedonic experience value and social experience value on satisfaction are 0.800 and 0.172 respectively. The original hypothesis is rejected, which indicates that hedonic experience value and social experience value will not have a significant impact on satisfaction. Therefore, we try to delete these two paths and modify the model. The results are shown in the following table. It can be found that the index is improved compared with the original model, and the GFI and AGFI are very close to 0.9, which is acceptable in the existing papers.

\section{Table6. Model parameters}

\begin{tabular}{|l|l|l|l|l|l|l|l|l|l|l|l|}
\hline & \multicolumn{3}{|l}{ Absolute fitness } \\
& $\chi^{2} / \mathrm{df}$ & RMR & RMSEA & GFI & AGFI & NFI & RFI & IFI & TLI & CFI \\
\hline & $<3$ & $<0.05$ & $<0.08$ & $>0.9$ & $>0.9$ & $>0.9$ & $>0.9$ & $>0.9$ & $>0.9$ & $>0.9$ \\
\hline $\begin{array}{l}\text { Recommended } \\
\text { standard }\end{array}$ & 2.241 & 0.021 & 0.076 & 0.897 & 0.831 & 0.917 & 0.897 & 0.952 & 0.94 & 0.952 \\
\hline $\begin{array}{l}\text { Original } \\
\text { model }\end{array}$ & 1.932 & 0.019 & 0.066 & 0.898 & 0.859 & 0.928 & 0.911 & 0.964 & 0.955 & 0.964 \\
\hline $\begin{array}{l}\text { Modified } \\
\text { model }\end{array}$ & & & & & & & & & & &
\end{tabular}

The path results after model modification are shown in Table 7, $\mathrm{P}$ values are all significant, indicating that the original hypothesis is tenable, that is to say, the economic experience value and altruistic experience value of Marathon participants will have a positive impact on satisfaction, and satisfaction will further affect their willingness to participate. Figure 1 intuitively shows the relationship among the three, the impact of economic experience value on satisfaction is higher than altruistic experience value, and satisfaction has the highest impact on willingness to participate.

Table7. Path analysis results of modified model

\begin{tabular}{|c|c|c|c|c|}
\hline Hypothetical path & $\begin{array}{c}\text { Standardized } \\
\text { regression coefficient }\end{array}$ & $\begin{array}{c}\text { Critical ratio } \\
\text { (C.R.) }\end{array}$ & P value & Test results \\
\hline $\begin{array}{c}\text { Satisfaction<---Economic } \\
\text { experience value }\end{array}$ & 0.691 & 7.693 & $* * *$ & True \\
\hline $\begin{array}{c}\text { Satisfaction<--- Altruistic } \\
\text { experience value }\end{array}$ & 0.343 & 5.226 & $* * *$ & True \\
\hline $\begin{array}{c}\text { Willingness to participate<--- } \\
\text { Satisfaction }\end{array}$ & 0.885 & 11.270 & $* * *$ & True \\
\hline
\end{tabular}




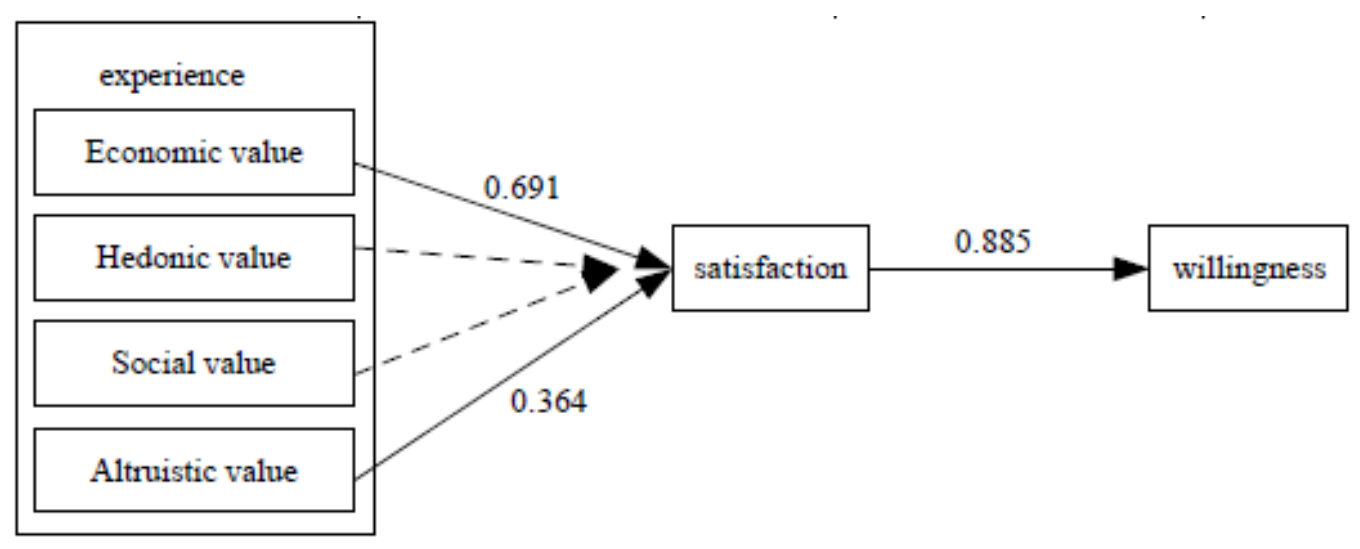

Figure1. Relationship among experience, satisfaction and willingness to participate

\section{CONCLUSIONS AND DISCUSSIONS}

This paper examines the relationship among the experience, satisfaction and willingness to participate through the structural equation model, and makes the following conclusions:

(1) The experience of Marathon participants can be divided into four dimensions. According to the survey, the experience perceived by participants is economic experience value (3.98), pleasure experience value (3.96), altruistic experience value (3.89), and social experience value (3.82). It can be found that the marathon participants have high experience values, and the experience obtained is not only from their own perspective, but also from the positive energy which is brought into the society by this competition. This can also be found in the text analysis of post competition perception in which different participants have related descriptions in four aspects. The value of economic experience is reflected in the low cost and the ability to know the local conditions around the track. The value of enjoyment is reflected on the participants' inner pleasure, beautiful scenery, harmonious relationship and so on. Altruistic experience value is reflected on the stress-free communication with other participants, and the affirmation of the positive image of marathon. The value of social experience is reflected in the improvement of participants' self, performance or mentality.

(2) The value of economic experience and altruistic experience will influence the satisfaction of participants, and then affect their willingness to continue to participate. Among them, the value of economic experience has the greatest impact on satisfaction. From the perspective of economic experience, running is a way to get people's physical and mental health with low cost. Participating in marathon is a challenge to personal achievements, which can enhance pride, and thus will have a great impact on satisfaction. Meanwhile, from the perspective of participants, marathon is altruistic. The free and easy communication with other runners, the positive characteristics of the event itself can make it have higher satisfaction with the activities.

(3) Hedonic experience value and social experience value have no significant impact on satisfaction. The possible reason is that although participants have a high degree of recognition of these two experiences, the effects of improving their sense of pride and feeling happy are short-lived, and the process of marathon running is not easy. If they heavily pursuit the results, it will produce obvious psychological pressure, so it can not significantly improve their satisfaction.

(4) The higher satisfaction they feel, the higher willingness to participate they have. This is consistent with the results of previous researches. For example, the value of economic experience mentioned above will bring higher satisfaction. Some participants pointed out in their choice of future marathon activities that they will not participate in those with extremely high cost. At the same time, altruistic experience also brings higher satisfaction, so there will be some new relationships in this value, and the probability of participating in marathon together will be higher.

As the conclusion shows, altruistic experience value is recognized by marathon participants. Although marathon, as a positive and healthy sports event, is consistent with the general background of national health, and can enhance residents' enthusiasm for participating in physical exercise, due to the long race schedule, there will be a long time of road closure, and the influx of large numbers of participants will also increase the congestion of the city. In recent years, in running activities, cheating and other 
negative events continue to appear, which also makes people have more understanding of the irrational prosperity of marathon. In this context, as the organizer, the identity of the participants should be examined, and there should be binding regulations on their behavior. Participants should also regulate their own behavior, not deliberately cater to the excessive needs of exclude-running spirit, in order to realize the rational return of healthy and positive image of Marathon activities.

\section{ACKNOWLEDGEMENT}

This study is funded by Philosophy and Social Science Foundation of Shenzhen (No.SZ2019C007).

\section{REFERENCES}

[1] Ahn J, Lee C, Back K, Schmitt A. Brand experiential value for creating integrated resort customers' cocreation behavior[J]. International Journal of Hospitality Management, 2019, 81:104-112.

[2] Chang S.(2018).Experience economy in hospitality and tourism: Gain and loss values. Tourism Management, 64:55-63

[3] Huang M., Zhang M.(2019). Cognition of place in embodied practice: Non-representational theory and Nanjing Marathon. Geographical Research, 38(6):1355-1366.

[4] Li J., Fan X. (2006). An Empirical Research on Three Dimension Service Experiences. Tourism Science, (2), 54-59.

[5] Li Q.(2017). Study on the influence mechanism of tourist environmental responsible behavior from the perspective of leisure experience. Journal of Anqing Normal University (Natural Science Edition),(03),7275 .

[6] Li X., Li W..(2019). Phenomenological Study of Psychological Experience of Urban Marathon Runners. Journal of Sports Adult Education, (3),54-58.

[7] Mathwick C., Malhotra N., Rigdon E.(2001). Experiential value: Conceptualization, measurement and application in the catalog and Internet shopping environment. Journal of Retailing, 77(1):39-56.

[8] Michie S., Gooty J. V.(2005).emotions and authenticity: Will the real leader please stand up? Leadership Quarterly, (16) : 441-457.

[9] Pine B. J., Gilmore J. H.(1998). Welcome to experience economy. Harvard Business Review, (7) : 97105.

[10] Prebensen N. K. , Woo .E., Uysal M. S.(2014) . Experience value: antecedents and consequences. Current Issues in Tourism, 17(10):910-928.

[11] Schmitt B. H.(1999). Experiential Marketing: How to Get Customers to Sense, Feel, Think, Act and Relate to Your Company and Brands. New York: The Free Press.

[12] Song B., YaoW.. (2013). Research on Experiential Exhibition-Taking Muji Outdoor Products Exhibition in Japan as an example. Tourism overview,(14),308-309.

[13] Sweeney J. C., Soutar G. N.(2001) . Consumer perceived value: The development of a multiple item scale. Journal of Retailing, 77(2):203-220.

[14] Wang J.. (2018)Running Self: the urban Marathon culture in the consumer society. New Horizons from Tianfu, (5):136-142.

[15] Wang J., Yang J. (2017). Communitarianism Metaphor and Rational Thinking of Marathon Phenomenon in China. Journal of Chengdu Sport University, (6),34-38.

[16] Wen T.(2007). The Development, Comparison and Prospects of Customer Experiential Theories. Journal of Sichuan University (Philosophy and Social Science Edition),(2):133-139.

[17] Wu, M. (2010). Structural equation modeling: AMOS operating and application. Chongqing University Press.

[18] Wu H. C., Cheng C. C. , Ai C. H.(2018) . A study of experiential quality, experiential value, trust, corporate reputation, experiential satisfaction and behavioral intentions for cruise tourists: The case of Hong Kong. Tourism Management, 66:200-220.

[19] Wu H. J. , Liang R. D.(2009) . Effect of experiential value on customer satisfaction with service encounters in luxury-hotel restaurants. International Journal of Hospitality Management, 28(4):586-593.

[20] Yang Y., Chen Y.(2010). An Exploration of Customer Experience in Resort Hotels and Its Empirical Enlightenment. Tourism Tribune, (4),49-54.

[21] Yu J., Zhang J.(2015). A Study of the Relationship between Tourist Experiential Value, Tourist Satisfaction and Tourist Loyalty_— Taking Hot Spring Tourism for Example. Journal of Liaoning University (Philosophy and Social Sciences Edition), (2), 75-81. 

under Experience Value Perspective

\section{AUTHOR'S BIOGRAPHY}

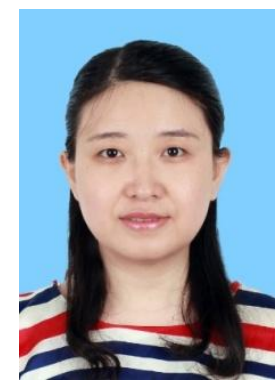

Dr. WenminJin, is a lecturer at the Shenzhen Campus of Jinan University, P.R. China (Shenzhen, Guangdong, China; E-mail: jin_wm@sz.jnu.edu.cn). She hasfocused her research on the area of event management.

Citation: Wenmin Jin. "Research on the Relationship Between Marathon Participants' Satisfaction and Willingness to Participate under Experience Value Perspective" International Journal of Managerial Studies and Research (IJMSR), vol 9, no. 6, 2021, pp. 01-10. doi: https://doi.org/10.20431/2349-0349.0906001.

Copyright: () 2021 Authors. This is an open-access article distributed under the terms of the Creative Commons Attribution License, which permits unrestricted use, distribution, and reproduction in any medium, provided the original author and source are credited. 